\title{
DETERMINANTS OF ALLOCATIVE (PRICING) EFFICIENCY OF CASSAVA FARMS IN IMO STATE, NIGERIA
}

\section{G.C Onubuogu and N.S Esiobu}

Department of Agricultural Economics, Extension and Rural Development, Imo State University, Owerri, Nigeria

Corresponding author: onugilock_chin@yahoo.com

\begin{abstract}
Globally and particularly across Sub-Saharan Africa of which Nigeria is included, cassava is one of the mostly cultivated and useful root crop. These crop not only contribute to the share of agriculture in national economy, but possess a great potential and comparative advantage to compete in the liberalized economy. Despite all these potentials of cassava, empirical studies on the allocative efficiency of cassava farms have not been fully and systematically documented in the area. Incidentally, most empirical studies on cassava have focused mainly on participation and adoption of cassava technologies. These create a gap in research. Empirical evidence on the allocative efficiency of cassava farm remains largely scanty and isolated. It was on this backdrop that the study was rigorously undertaken. Specifically, the study determined the allocative efficiency of cassava farms. Multistage random sampling technique was used in the selection of respondents. Sample size comprised ninety (90) cassava farms. Well structured questionnaire was the main tool for data collection. Data collected were analyzed using stochastic frontier production model and cost function. The estimated gamma $(\gamma)$ parameter of stochastic frontier production function showed that about $82.7 \%$ variation in output among cassava farmers in the study area was due to differences in relative efficiency. The return to scale (RtS) was 0.549 in the study area. This indicates a positive decreasing return to scale and that cassava production was in stage II of the production region where resources and production were believed to be efficient. The mean allocative efficiency was 0.860. The policy implication of these findings is that cassava farms were efficient in allocating their resources considering their scope of operation and the limited resources in the study area. It was recommended that farmers particularly on their own should judiciously pool productive resources together through strengthened and stable cooperative society group as this would enhance their relative efficiencies in cassava production positively in the area.
\end{abstract}

Keywords: Allocative efficiency; Cassava; stochastic frontier production model; Imo State https://dx.doi.org/10.4314/jafs.v17i2.8 


\section{INTRODUCTION}

Allocative (Pricing) Efficiency (AE) refers to the ability of a firm to produce at a given level of output using the cost-minimizing input ratios (Ettah and Angba, 2016). In Nigeria, root and tuber crops such as cassava (Manihot spp.) have a significant place in the economy (International Institute of Tropical Agriculture (IITA) (2016) and Nigeria Bureau of Statistics (NBS) 2016). These crops not only contribute to the share of agriculture in national economy, but possess a great potential and comparative advantage to compete in the liberalized. Similarly, cassava is grown by almost every household in Nigeria and serves more as a major source of income especially for the increasing rural dwellers (Onubuogu, Esiobu, Nwosu, Okereke, 2014). Cassava is also identified as a promising crop for international trade, as demand for cassava derivatives, e.g. garri (a type of processed cassava), starch and tapioca doubled over the last two decades. Presently, Nigeria is the world largest producer of cassava with an annual production capacity of 54 million tons of tuberous roots; being almost $19 \%$ of the total world production capacity of 215,344,296 million tons, a third more than Brazil and almost double the production capacity of Thailand and Indonesia respectively (Food and Agricultural Organization (FAO), (2016) and Federal Ministry of Finance (FMF), 2017). As a food crop, cassava has some significant inherent characteristics which make it attractive especially to farmers in Nigeria. Firstly, it is rich in carbohydrates, especially starch, and consequently has multiplicity of end uses Secondly, it is available all the year round, making it preferable to other more seasonal crops such as grains, peas, beans and other crops for food security and lastly it is tolerant of low soil fertility and more resistant to drought, Cassava tubers are mostly processed into cassava flour (lafun). Cassava flour is dried and powdered form of cassava, garri is fried granulated form of cassava while fufu is fermented pounded form of cassava) in Nigeria (Oni, 2016). Cassava can also be cooked or eaten, pounded and consumed in its raw form, most especially the sweet variety (Oyewo, Adepoju, Ojo, Oyewo, Atanda, 2016). By implication, cassava has become a regular item in household diets in Nigeria (Lora, Posthumus and Martin, 2016). One of the ways in which optimal allocative efficiencies could be achieved is to improve the productivity of cassava farms in the study area. However, such information allocative efficiencies of cassava farms is lacking in Imo State, Nigeria. A significant and valid contributions have been made by various researchers (Adewuyi, Agbonlahor and Oke, 2013; Onumadu et al., 2014; Riatania, Daryanto, Tambunan and Purwati, 2014; Ogunniyi, 2015; Eze, Ohajianya, Ibeagwa and Ojinnaka, 2015) at various household level in understanding the concept of allocative efficiency. Incidentally, a number of empirical studies on cassava production have focused more on economic analysis (Nwaiwu, Odii, Ohajianya, Eze, Oguoma, Ibekwe, Henri-Ukoha, Kadiri, Amaechi and Ogun, 2010), production constraint (Chidiebere-Mark, Nwosu, Nwankwo, C. Chikezie, Oduofor and Ejike, 2014), participation and level of adoption of cassava technologies (Nnadi, Chikaire, Umunnakwe and Ihenacho, 2013). Similarly, other studies (Ibekwe, Orebiyi, Henri-Ukoha, Okorji, Nwagbo and Chidiebere-Mark, 2012) that attempted to estimate the relative efficiencies of cassava farmers in Imo State, used the ordinary least squares (OLS) estimation techniques. 
The use of the ordinary least squares (OLS) estimating technique makes it difficult to determine farm level efficiency as it provides only an average function (Ohajianya, Mgbada, Onu, Enyia, Henri-Ukoha, Ben-Chendo and Godson-Ibeji, 2013) though it provides consistent estimates of the parameters except the intercept (Ogunyinka et al., 2014). To overcome this shortcoming of the OLS, the stochastic frontier function was developed to estimate efficiency of agricultural production. Its beauty lies in its ability to test and quantify the inefficiency of individual farmers in a sample because it allows for statistical noise rather than attributing all deviation to efficiency. It is also straight forward to implement and interpret. A situation that is not possible with other partial measures of efficiency such as the OLS. Furthermore, little or no study has rigorously estimated the allocative efficiency of cassava farm in Imo State, Nigeria. Only the studies of Onumadu et al., (2014) attempted to estimate the concept of allocative efficiency but his study failed to focus specifically on cassava farms and in the same vein was conducted in Anambra State which cannot be said to be a true position and representation of Imo State, Nigeria. It is on these backdrops that the study was rigorously undertaken.

\section{MATERIALS AND METHODS}

The study was carried out in Imo State, Nigeria. The State is located in the rainforest agroecological region of Nigeria and shares common boundaries with Abia State on the east and northeast, Rivers State on the south, and Anambra State on the west and northwest (Imo State Agricultural Development Project (Imo-ADP, 2013). The State lies between Latitudes $5^{\circ} 45^{1}$ and $6^{\circ} 35^{1}$ North of the equator and Longitudes $6^{\circ} 35^{1}$ and $7^{\circ} 28^{1}$ East of the Greenwich Meridian (Chineke et al., 2011). It occupies the area between the lower River Niger and the upper and middle Imo River (Imo-ADP, 2013). It is bounded on the east by Abia State, on the west by the River Niger and Delta State and on the north by Anambra State, while Rivers State lies to the south (Imo State Ministry of Land and Survey and Urban Planning, 2013). Imo State covers an area of about $5,067.20 \mathrm{~km}^{2}$, with a population of 3,934,899 persons with many subsisting farmers (Nigeria Population Commission (NPC), 2006 and National Bureau of Statistics (NBS), 2007) and population density of about $725 \mathrm{~km}^{2}$ (Imo-ADP, 2015). The State has an average annual temperature of $28^{\circ} \mathrm{C}$, an average annual relative humidity of $80 \%$, average annual rainfall of 1800 to $2500 \mathrm{~mm}$ and an altitude of about 100m above sea level (Imo-ADP, 2013).

The State has three agricultural zones namely Orlu, Owerri, and Okigwe agricultural zones. Farming is the main occupation of the rural dwellers in the State. The farmers produce both root and tuber crops of which cassava are predominant. The sample for the study was drawn from cassava farmers in the study area. A multi-stage random sampling technique was adopted in the selection of respondents for the study. Firstly, three Local Government Areas (LGAs) were randomly selected from each of the agricultural zone (Orlu, Owerri and Okigwe) in Imo State. The three (3) LGAs selected from Orlu agricultural zone of the State were Njaba, Orlu and Ideato-North. Similarly, the three (3) LGAs selected from Owerri agricultural zone of the State included Ikeduru, Mbaitoli and Owerri North. In the same vein, Ihitte-Uboma, Onuimo and Ehime Mbano were the three (3) LGAs selected from Okigwe agricultural zone. Furthermore, Journal of the Faculty of Agriculture and Veterinary Medicine, Imo State University Owerri website: www ajol.info 
three (3) communities were randomly selected from each of the sampled LGAs, selected from each of the three (3) agricultural zone of the State (Orlu, Owerri and Okigwe) to give a total number of twenty-seven (27) communities each from the area. Finally, four (4) households the three (3) LGAs selected from Owerri agricultural zone cassava farmers were randomly selected from each of the twenty-seven (27) communities to give a total sample size of one-hundred and eight (108) cassava farms for the study. Ultimately, from the retrieved questionnaires, only ninety (90) individual responses were found useful. The list of cassava farms in the communities, which forms the sample frame, was obtained from the zonal extension agents of Imo State Agricultural Development Programme (Imo-ADP) in the study area. Primary data was used for the study. Primary data was collected through the use of structured questionnaire and it was supplemented with oral interview in places where the respondents could neither read nor write. The objective was modelled using the stochastic frontier production function. The implicit form of the stochastic frontier production model is specified as follows;

$$
\begin{gathered}
\operatorname{Ln} Y i j=\beta o+\beta 1 \operatorname{Ln} X 1+\beta 2 \operatorname{Ln} X 2+\beta 3 \operatorname{Ln} X 3+\beta 4 \operatorname{Ln} X 4+\beta 5 \operatorname{Ln} X 5+\beta 6 \operatorname{Ln} X 6 \\
+(\boldsymbol{V} i-U i) \ldots \ldots \ldots \ldots \ldots \ldots \ldots . . . \ldots 25
\end{gathered}
$$

Where;

$\mathrm{Y}_{\mathrm{i}}=$ Cassava output $(\mathrm{kg})$

$\mathrm{X}_{1}=$ Farm size (Hectares)

$\mathrm{X}_{2}=$ Labour used (man days)

$\mathrm{X}_{3}=$ Fertilizer $(\mathrm{N})$

$\mathrm{X}_{4}=$ Equipments $(\mathrm{N})$

$\mathrm{X}_{5}=$ Cassava stem cuttings used $(\mathrm{N})$

$\mathrm{L}_{\mathrm{n}}=$ logarithm to base-e

$i j=j^{\text {th }}$ observation of the $i^{\text {th }}$ farmer

$\mathrm{V}_{\mathrm{i}}=$ Is a two-sided, normally distributed random error

$\mathrm{U}_{\mathrm{i}}=$ Is a one-sided efficiency component with a half-normal distribution

\section{RESULTS AND DISCUSSION}

\section{Maximum Likelihood Estimates of Stochastic Frontier Production Model}

The results of estimates of production and cost functions are presented in table 1 . The estimate of the parameters of the stochastic frontier production model reveals that all the estimated coefficients of the variables of the production function were positive except for that of fertilizer and equipment. The two significant variables are farm size and cassava stem cuttings which were 
statistically significant at $1 \%$ and $5 \%$ level respectively. The estimate of sigma square $\left(\sigma^{2}\right)$ of 419.52 was statistically significant at $5 \%$ level and therefore, assures us of the goodness of fit and correctness of the distributional assumptions of the composite error. The estimated gamma parameter $(\gamma)$ of 0.827 indicates that $82.7 \%$ of the total variation in cassava output was due to differences in their technical inefficiency. It also gives an indication that the unexplained variations in output are the major sources of random errors. It also confirms the presence of the one-sided error component in the model and hence, the use of the Ordinary Least Square (OLS) in estimating the function, becomes inadequate in representing the data. The Return to Scale (RtS) was 0.549 , which indicates a positive but decreasing return to scale. The findings shows that the farmers were operating at the stage II of the production function, hence, resources and production could be efficient at this stage. The generalized likelihood test gave a value of 915.53 which indicates that the farmers are not fully technically efficient. Similarly, the result of the stochastic frontier cost function in table 4.13 reveals that all the independent variables gave a positive coefficient. The result implies that as these factors increased, total production cost increased ceteris paribus. The significant variables are depreciation on farmland, cost of cassava stem cuttings, cost of labour and output which were statistically significant at $10 \%, 1 \%, 5 \%$ and $5 \%$ respectively. The gamma $(\gamma)$ estimate was 0.914 and was significant at $1 \%$ level indicating that $91.5 \%$ of the variations in output were caused by economic inefficiency. The sigma square $\left(\delta^{2}\right)$ was 4.312 and was significant at $1 \%$ level, and indicated the goodness of fit and correctness of the specified assumptions of the distribution of the compound error term. The generalized likelihood test gave a value of -3311.561 which indicates that the farmers are not fully economically efficient.

Furthermore, the inefficiency result is presented in table 4.13. The educational level had a positive coefficient with efficiency of the cassava farmers; hence it is statistically significant at $1 \%$ level of probability. This implies that increase in year of formal education leads to decrease in inefficiency of the farmers. It means that farmers with higher years of education are in a better position to be more technically efficient than their counterparts. It is very possible that farmers with higher level of education respond easily to the use of improved technology, such as the application of fertilizers, use of pesticides, herbicides and so on thus assisting the farmers to produce close to the frontier. This finding is in conformity with the finding of Ogunniyi (2015) who reported a positive relationship between education and technical efficiency. This shows that education is an important factor that reduces inefficiency among cassava farmers in the study area. The membership of cooperative had a positive coefficient with efficiency of the cassava farmers and it was statistically significant at $1 \%$ level of probability. This implies that cassava farmers who belong to cooperative society gather more information, exchange labour, acquire reasonable amount of credit and knowledge on how to efficiently use production resource to enhance their output than those who do not belong to any agricultural cooperative society. Membership of cooperative gives farmers easy access to farm credit, share information, ideals and project a collective demand (Tijjani and Bakari, 2014). Similarly, the studies of Aboki et al., 
(2013) and Idris et al., (2013) opined that membership of cooperative was positive and significantly related to relative efficiency of farmers. The finding is supported by the result of Berhan (2016) who argued that the more active the farmers are in their involvement in the farmer association, the more information of farm activities carried out and agricultural input distribution they have compared to those who do not join the association. The extension contact was found to be positively related to the efficiency of the cassava farmers. This implies that farmers who received more visit and/or in frequent contact with extension staff/agents are in a better position of being technically efficient in the use of production resources to enhance their agricultural production than those who receive little or no visit. The relationship is significant at $1 \%$ level of probability. The study of Nwaiwu et al., (2015) argued that extension contact enhance farmers production and promote their knowledge on modern farming methods. The findings of Ochi et al., (2016) showed extension contact was positive and significantly related to relative efficiency of cassava farmers. Household size had a negative coefficient with the inefficiency of the cassava farmers. This implies that farmers with larger household size were more technically efficient than smaller household size. The implication of the negative coefficient of household size is that it contributes to resource use efficiency in cassava production in the study area. The effect of household size on farm level resource use efficiency is traceable to its use as a source of labour supply for work on the farm. In some instances, family labour may be forced resulting in drudgery and poor workmanship. This relationship is significant at the $1 \%$ level of probability. This finding support the result of Simpa et al., (2014) who reported that large household size is a proxy to labour availability, ensure ease allocation of resources and reduce the cost of hired labour. Farming experience had a positive coefficient with the inefficiency of the cassava farmers and hence it is statistically significant at $1 \%$ level of probability. This implies that increase in year of farming experience leads to increase in efficiency of the farmers. This implies that the more experienced cassava farmers know the problems involved in cassava production and are in a better position to overcome them and improve on their yield than those that had little or no experience. The studies of Ochi et al., (2016) and Berhan (2016) asserted that farming experience is positively and significantly related with efficiency of farmers. This implies that increase in year of farming experience leads to decrease in inefficiency of the farmers. Similarly, the findings is also in line with the study of Akhilomen et al., (2015) who reported that farmers with more years of farming experience would be more efficient, have better knowledge of climatic conditions, better knowledge of efficient allocation of resources and market situation and are thus, expected to run a more efficient and profitable enterprise.

\section{Estimation of Allocative Efficiency of the Cassava Farmers}

The results of estimates of allocative efficiency of the cassava farmers are presented in table 2 . The allocative efficiency analysis of cassava production revealed that there was presence of allocative efficiency effects in cassava production in the study area as confirmed by the gamma value of 0.827 that was significant at $5 \%$ level of probability. The gamma $(\gamma)$ value of 0.827 implies that about $82.7 \%$ variation in the output of cassava farmers was due to differences in 
their allocative efficiencies. The predicted allocative efficiencies (AE) range between 0.412 and 0.980 while the mean $\mathrm{AE}$ was 0.860 . The result also showed that there is ample opportunity for improvement on the level of allocative efficiency in cassava production in the study area. Similarly, the finding shows that if the average cassava farmer in the area was to achieve the AE level of its most efficient counterpart, then the average farmer could realize about $12.30 \%$ of cost saving [i.e., 1-(98.0/86.0) x100]. A similar calculation for the most allocative inefficient farmer reveals cost saving of approximately 53.00\% [i.e., 1-(41.2/86.0)x100]. Moreover, the frequencies of occurrences of the predicted allocative efficiencies in deciles range indicate that the highest number of farmers have allocative efficiencies between $0.90-0.99$. The sample frequency distribution indicates a clustering of allocative efficiencies in the region $0.90-0.99$ efficiency ranges, representing $58.89 \%$ of the cassava farmers in the area. This implies that the farmers are fairly allocatively efficient. That is, the farmers are fairly allocatively efficient in producing cassava at a given level of output using the cost minimizing input ratio as approximately $90.66 \%$ of the farmers have $\mathrm{AE}$ of 0.70 and above. This implies that the farmers are fairly allocative efficient. That is, the farmers are efficient in deriving maximum output from input, given the available resources. The study of Onu and Edon, (2009) and Simpa et al., (2014) reported that training/orientation to the farmers, especially towards the new technology and other farming practices improve allocative efficiency of farmers. The result revealed that farmers in the study area are fairly efficient in producing cassava at a given level of output using the cost minimizing input ratio. The study further revealed ample opportunity that exists for improving the level of allocative efficiency of cassava production in the study area. The results tallies with the studies of Obike et al., (2016) and Nwike et al., (2017) who reported the allocative inefficiencies of cassava farmers in cassava production.

\section{CONCLUSION AND RECOMMENDATION}

The estimated gamma $(\gamma)$ parameter of stochastic frontier production function showed that about $82.7 \%$ variation in output among cassava farmers in the study area was due to differences in relative efficiency. The result of the study showed that the major factor affecting cassava productions in the study area were educations, membership of cooperative, extension contact, farming experiences and farm size, household size, labour and fertilizer. These factors have positive influence on cassava output. The return to scale (RtS) was 0.549 in the study area. This indicates a positive decreasing return to scale and that cassava production was in stage II of the production region where resources and production were believed to be efficient. The mean allocative efficiency was 0.860 . The policy implication of these findings is that cassava farmers in the study area were efficient in allocating their resources considering their scope of operation and the limited resources. 
These recommendations were made based on the major findings of the study;

Farmers particularly on their own should judiciously pool productive resources together through strengthened and stable cooperative society groups as this would enhance their relative efficiencies in cassava production positively in the area.

(i) Effective agricultural policies and programmes should focus on granting farmers improved access to farm credit and subsidized inputs as these would enable them increase their production efficiencies positively in the area.

(ii) Government at all levels should identify genuine cassava farmers and grant them access to farmland as these would significantly increase their production efficiencies and standard of living positively in the area 


\section{REFERENCES}

Adewuyi, S.A, M.U Agbonlahor and A.T Oke (2013). Technical Efficiency Analysis Of Cassava Farmers In Ogun State, Nigeria; IJAFS Vol. 4. No 14: Pp: 515-522

Akhilomen, L.O, G. M. Bivan, S. A. Rahman and S. A. Sanni (2015). Economic Efficiency Analysis of Pineapple Production in Edo State, Nigeria: A Stochastic Frontier Production Approach; American Journal of Experimental Agriculture 5(3): 267-280

Berhan, T.H (2016). Determinants of Technical, Allocative and Economic Efficiencies among Onion Producing Farmers in Kobo District, Amhara Region, Ethiopia; Journal of Economics and Sustainable Development; 6(3):8-17

Chidiebere-Mark, N.M., C.S. Nwosu, O.O Nwankwo, C. Chikezie ,H.U Oduofor and R.D Ejike (2014). Profitability of cassava based crop farmers in owerri agricultural zone of Imo state, South-East Nigeria; Wudpecker Journal of Agricultural Research; Vol. 3(1), Pp. $010-015$

Chineke, T C, M.E, Idinoba and O.C, Ajayi (2011). Seasonal evapotranspiration signatures under a changing landscape and ecosystem management in Nigeria: Implications for agriculture and food security; Am. J. Sci. Ind. Res., 2(2): Pp; 191-204

Ettah, O. I and A.O Angba (2016).Analysis of Cost and Returns among Cassava Farmers in Cross River State, Nigeria; International Journal of Science and Research; Vol. 6.3; Pp; $111-114$

Federal Ministry of Finance (FMF) (2017); 2017 - 2019 Medium-Term Expenditure Framework and Fiscal Strategy Paper; accessed online Jan. 20; 2017; Budget Office of the Federation Ministry of Budget \& National Planning Abuja, Nigeria http://Www.Budgetoffice.Gov.Ng/Pdfs/2016/20172019\%20mtef\%20\&\%20fsp\%20executive\%20proposal.pdf

Food and Agricultural Organisation (2016). Production Crop: Cassava, 2016 date. Food and Agriculture Organization, Rome

Ibekwe, U.C, J. S. Orebiyi, A. Henri-Ukoha, E. C. Okorji, E. C. Nwagbo and N. M. ChidiebereMark (2012). Resource Use Efficiency in Cassava Production in South East Nigeria. Asian Journal of Agricultural Extension, Economics \& Sociology 1(1): 16-21,

Imo State Agricultural Development Programme (ADP) (2013). An Assessment Study of the Performance of the National Agricultural Technology Support Project in Imo State with Focus of Farmer Adoption of Technology and their Social Economic Improvements; Pp:1-34.

Imo State Agricultural Development Project (Imo-ADP) (2015). Imo ADP Extension Guide. A Paper Presented at the Imo ADP Pre-seeding; Training Workshop; Cochinta Nig. Ltd. February.

Journal of the Faculty of Agriculture and Veterinary Medicine, Imo State University Owerri website: www ajol.info 
International Institute of Tropical Agriculture (IITA)(2016). Overview of Root and Tuber Crops Potential in Nigeria; http://www.iita.org/overview/cassava; assessed on line on 12-102016

Kadiri, F. A.; C.C Eze, J.S Orebiyi, J.I Lemchi, D.O Ohajianya and I.U Naidu (2014). Technical Efficiency In Paddy Rice Production In Niger Delta Region Of Nigeria; Global Journal of Agricultural Research Vol.2, No.2, PP. 33-43

National Bureau of Statistics (NBS) (2007). National Bureau of Statistics Official Gazette (FGP 71/52007/2,500(OL24): Legal Notice on Publication of the Details of the Breakdown of the National and State Provisional Totals, 2006 Census. www.nigerianstat.gov.ng (accessed 28 February, 2016)

Nigeria Population Commission (NPC) (2006). Nigeria Population Commission, Nigeria Federal Government Initiative of individual head count by gender. Spread, State by State, In :MOFINEWS; (accessed 28 February, 2016).Jan-Feb,2007, 6(3):Nigeria.

Nnadi, F.N., C.D Nnadi, J. Chikaire, P.C Umunnakwe and R.A Ihenacho (2013). Analysis of Rural Cassava Farmers' Participation in the Nigeria Agricultural Insurance Scheme in Imo State, Nigeria; Global Journal of Science Frontier Research Agriculture and Veterinary; Volume 13 Issue 11 Version 1.0; Pp;38-45

Nwaiwu, I, M. Odii, D. Ohajianya, C. Eze, N. Oguoma, C. Ibekwe, A. Henri-Ukoha; F. Kadiri; C. Amaechi; J. Ogun,(2010). Comparative Analysis of the Productivity of Sustainable Cassava Farming Under External and Internal Input Use in Imo State Nigeria, New York Science Journal 3(10):Pp; 12-16.

Nwike, M.C., T.O Okoli, P. Oghenehogagame and C.O.A Ugwumba (2017). Economic Efficiency and Returns to Scale of Cassava Production in Southeast Nigeria. International Journal of Agriculture Innovations and Research Volume 6, Issue 1, 23191473

Ochi, J.E, R. M. Sani and F. K. Idefoh (2016). Economic Analysis of Resource Use Efficiency among Small Scale Cassava Farmers in Nasarawa State, Nigeria: Implications for Agricultural Transformation Agenda; International Journal of Research in Agriculture and Forestry; Vol.2, No. 2, Pp: 14-21

Ogunniyi, I.T (2015). Technical, allocative and economic efficiency of cassava producers in Oyo State of Nigeria; Scientia Agriculturae; Vol. 11.No. 2; Pp;53-59

Ogunyinka, A,I, J.O Bifarin, L.O Omoniyi (2014). Determinate of production efficiency of cocoyam farmers in Oru West Local Government area of Imo State, Nigeria; Proceeding of the $15^{\text {th }}$ Annual National Conference of the Nigerian Association of Agricultural Economist (NAAE); 24 ${ }^{\text {th }}-27^{\text {nd }}$ February, 2014; Federal University of Technology, Akure, Nigeria; Pp:170-180

Journal of the Faculty of Agriculture and Veterinary Medicine, Imo State University Owerri website: www ajol.info 
Ohajianya, D.O, J. U. Mgbada, P. N. Onu, C. O. Enyia, A. Henri-Ukoha, N. G. Ben-Chendo and C. C. Godson-Ibeji (2013). Technical and Economic Efficiencies in Poultry Production in Imo State, Nigeria; American Journal of Experimental Agriculture 3(4):927-938

Ohen, S B; D.E Ene and G.E Umeze (2014). Resource Use Efficiency of Cassava farmers in Akwa Ibom State, Nigeria; J. Bio. Agric. and Healthcare, 4 (2): 126-131

Okoye, F.U (2016). Gender and Resource Use Efficiency in Cocoyam Production In Anambra State, Nigeria; An M. Sc Dissertation Submitted To The Department Of Agricultural Economics University Of Nigeria, Nsukka

Oni, T.O (2016). Socio-economic determinants and profitability of cassava production in Nigeria; International Journal of Agricultural Economics and Extension; Vol. 4 (4), Pp. 229-249

Onubuogu, G.C and S.A.N.D Chidebelu (2012).Technical Efficiency Evaluation of Market Age and Enterprise Size for Broiler Production in Imo State, Nigeria; Nigeria Agricultural Journal, $\underline{43}(2)$

Onubuogu, G.C, Esiobu N.S, Nwosu C.S, Okereke C.N (2014). Resource use efficiency of smallholder cassava farmers in Owerri Agricultural zone, Imo State, Nigeria; Scholarly J. Agric. Sci. 7(8):142-152

Onubuogu. G. C., Chidebelu, S, A. N. D. and Eboh, E. C. (2013). Enterprise Type, Size and Allocative Efficiency of Broiler Production in Imo State, Nigeria. Int. J. Appl. Res. Technol. 2(6): $10-19$

Onumadu, F. N, G.N Ekwugha,E.E Osahon (2014). Resource Use Efficiency In Arable Crop Production In Oyi Local Government Area, Anambra State, Nigeria. International Journal of Scientific \& Technology Research, 3 (1):230-235

Oyewo, I.O, A.O Adepoju, M.O Ojo, E.O Oyewo, G.O Atanda (2016). Land Management Practices on Cassava Production in Akinyele Local Government Area, Oyo State Nigeria; Scientia Agriculturae; 15 (1): 329-333

Riatania, L., A., Daryanto, M., Tambunan and H., Purwati (2014). Technical, Allocative and Economic Efficiency of Pineapple Production in West Java Province, Indonesia: A DEA Approach; IOSR Journal of Agriculture and Veterinary Science, 7(6): 18-23

Simpa, J.O, J. N Nmadu and A. Okino (2014). Technical Efficiency of Smallholder Cassava Farmers in Selected Local Government Areas in Kogi State, Nigeria; PAT; 10 (1): Pp: 74-92 


\section{APPENDIXES}

Table 1. Maximum Likelihood Estimate of Stochastic Frontier Models

\begin{tabular}{|c|c|c|c|c|c|c|c|}
\hline $\begin{array}{l}\text { Production } \\
\text { variables }\end{array}$ & Parameters & Coefficient & t-value & Cost function variables & Parameters & Coefficient & t-value \\
\hline Constant & $\beta_{0}$ & 35.249 & $6.842 * * *$ & Constant & $\beta_{0}$ & -437.528 & $-7.610 * * *$ \\
\hline Land & $\beta_{1}$ & 0.372 & $5.092 * * *$ & Depreciation on Land & $\beta_{1}$ & 0.311 & $1.992 *$ \\
\hline Cassava stem Cutting & $\beta_{2}$ & 0.215 & $3.575^{* *}$ & Cost of Cassava stem Cutting & $\beta_{2}$ & 1.302 & $6.201 * * *$ \\
\hline Labour & $\beta_{3}$ & 0.017 & 0.025 & Cost of Labour & $\beta_{3}$ & 0.085 & $2.405 * *$ \\
\hline Fertilizer & $\beta_{4}$ & -0.024 & -0.310 & Cost of Fertilizer & $\beta_{4}$ & 0.115 & 0.050 \\
\hline Equipments & $\beta_{5}$ & -0.031 & -0.550 & Cost of Equipments & $\beta_{5}$ & 0.273 & 1.005 \\
\hline Inefficiency Factor & & & & Output & $\mathrm{Y}$ & 188.842 & $3.957 * *$ \\
\hline Education & $\mathrm{Z}_{1}$ & 0.381 & $4.203 * * *$ & Sigma - square & $\sigma^{2}$ & 472.532 & $4.312 * *$ \\
\hline $\begin{array}{l}\text { Membership of } \\
\text { cooperative }\end{array}$ & $\mathrm{Z}_{2}$ & 0.262 & $3.271 * * *$ & Gamma & $\gamma$ & 0.914 & $5.853 * * *$ \\
\hline
\end{tabular}

Journal of the Faculty of Agriculture and Veterinary Medicine, Imo State University Owerri website: www ajol.info 


\begin{tabular}{|c|c|c|c|c|c|c|}
\hline Extension contact & $\mathrm{Z}_{3}$ & 0.201 & $3.191 * * * *$ & Log - Likelihood function & $L(\theta)$ & -3311.561 \\
\hline Household size & $\mathrm{Z}_{4}$ & -0.305 & $-4.111 * * *$ & & & \\
\hline Farming experiences & $\mathrm{Z}_{5}$ & 0.227 & $3.010 * * *$ & & & \\
\hline Sigma - square & $\sigma^{2}$ & 419.52 & $4.026^{* * * *}$ & & & \\
\hline Gamma & $\Gamma$ & 0.827 & $10.738 * * *$ & & & \\
\hline Log - Likelihood function & $L(\theta)$ & -915.53 & & & & \\
\hline Return to Scale & $(\mathrm{RtS})$ & 0.549 & & & & \\
\hline Sample size & $\mathrm{N}$ & 90.00 & & & & \\
\hline
\end{tabular}

*Statistically Significant at $10 \%$;*Statistically Significant at $5 \%$; *** Statistically Significant at $1 \%$; Source: Frontier 4.1 (2018) 
Journal of Agriculture and Food Sciences

Onubuogu, G.C and Esiobu, N.S. ${ }^{99}$

Volume 17 Number 2, October 2019 pp 86 - 99.

Table 2. Deciles Range of Frequency Distribution of Allocative Efficiency of the Cassava Farmers

\begin{tabular}{lll}
\hline Efficiency Level & Frequency & Percentage (\%) \\
\hline $\mathbf{0 . 4 0 - 0 . 4 9}$ & 2 & 2.22 \\
$\mathbf{0 . 5 0 - 0 . 5 9}$ & 1 & 1.11 \\
$\mathbf{0 . 6 0 - 0 . 6 9}$ & 9 & 10.00 \\
$\mathbf{0 . 7 0 - 0 . 7 9}$ & 12 & 13.33 \\
$\mathbf{0 . 8 0 - 0 . 8 9}$ & 20 & 22.22 \\
$\mathbf{0 . 9 0 - 0 . 9 9}$ & 46 & 55.11 \\
Total & 90.0 & 100.0 \\
Mean & 0.860 & \\
Standard Deviation & 0.026 & \\
Minimum & 0.412 & \\
Maximum & 0.980 & \\
\hline
\end{tabular}

Source: Frontier 4.1 (2018)

Journal of the Faculty of Agriculture and Veterinary Medicine, Imo State University Owerri website: $w w w$ ajol.info 